\title{
Ultrahigh and Tunable Electromagnetic Interference Shielding Performance of PVDF Composite Induced by Nano-Micro Cellular Structure
}

\author{
Yang Yang ${ }^{\mathbb{D}}$, Shuiping Zeng, Xiping Li *, Zhonglue Hu and Jiajia Zheng
}

Citation: Yang, Y.; Zeng, S.; Li, X.; $\mathrm{Hu}, \mathrm{Z}$.; Zheng, J. Ultrahigh and Tunable Electromagnetic Interference Shielding Performance of PVDF Composite Induced by Nano-Micro Cellular Structure. Polymers 2022, 14, 234. https://doi.org/10.3390/ polym 14020234

Academic Editor: Jiquan Li

Received: 4 December 2021

Accepted: 6 January 2022

Published: 7 January 2022

Publisher's Note: MDPI stays neutral with regard to jurisdictional claims in published maps and institutional affiliations.

Copyright: (C) 2022 by the authors. Licensee MDPI, Basel, Switzerland. This article is an open access article distributed under the terms and conditions of the Creative Commons Attribution (CC BY) license (https:// creativecommons.org/licenses/by/ $4.0 /$ )
Key Laboratory of Urban Rail Transit Intelligent Operation and Maintenance Technology \& Equipment of Zhejiang Province, Zhejiang Normal University, Jinhua 321004, China; yanghqu@163.com (Y.Y.); bww2019@yeah.net (S.Z.); zhonglue.hu@zjnu.edu.cn (Z.H.); jiajia.zheng@zjnu.cn (J.Z.)

* Correspondence: xp12005@163.com

\begin{abstract}
Lightweight and efficient electromagnetic interference (EMI) shielding materials play a vital role in protecting high-precision electronic devices and human health. Porous PVDF/CNTs/urchinlike Ni composites with different cell sizes from nanoscale to microscale were fabricated through one-step supercritical carbon dioxide $\left(\mathrm{CO}_{2}\right)$ foaming. The electrical conductivity and electromagnetic interference (EMI) shielding performance of the composites with different cell sizes were examined in detail. The results indicated that the nanoscale cell structure diminishes the EMI shielding performance of the composite, whereas the microscale cell structure with an appropriate size is beneficial for improving the EMI shielding performance. A maximum EMI shielding effectiveness (SE) of $43.4 \mathrm{~dB}$ was achieved by the composite foams which is about twice that of the solid composite. Furthermore, as the supercritical $\mathrm{CO}_{2}$ foaming process reduces the density of the composite by $25-50 \%$, the EMI SSE (specific shielding effectiveness)/ $t$ (thickness) of the composite reaches $402 \mathrm{~dB} /\left(\mathrm{g} / \mathrm{cm}^{2}\right)$, which is the highest value of polymer foam obtained to the best of the authors' knowledge. Finally, compression tests were performed to show that the composites still maintained excellent mechanical properties after the supercritical $\mathrm{CO}_{2}$ foaming process.
\end{abstract}

Keywords: composite; supercritical $\mathrm{CO}_{2}$ foam; cell size; EMI shielding

\section{Introduction}

In recent years, with the rapid development of 5G wireless communication technology, the spatial layout of communication equipment tends to be miniaturized, dense, and largescale [1-3]. However, the resultant electromagnetic wave pollution can cause high-precision electronic devices to malfunction and even lead to human health problems. Therefore, lightweight, flexible, and efficient electromagnetic interference (EMI) shielding materials have always been hot research issues for scientists [4-6].

Typically, common metallic EMI shielding materials have drawbacks of high density, easy corrosion, and difficult shaping, which restricts its application in special fields such as aerospace and open-air environments [7-9]. Thus, new conductive polymer composites have been widely recognized by researchers for their unique features such as light-weight, corrosion resistance, and ease of molding [10-12]. At present, carbon-based conductive composite materials belong to the widely studied EMI shielding materials. Due to the low density, high aspect ratio, and excellent electrical conductivity, the carbon nanofillers such as carbon nanotubes, graphite sheets, graphene nanoplates, and carbon fibers, etc., allow composites with extremely low content to exhibit excellent EMI shielding performance. In addition, magnetic nano-fillers are used for embedding in conductive composites to improve their EMI shielding properties due to their magnetic loss ability in attenuating electromagnetic waves. For example, Zhao et al. [13] prepared PVDF (polyvinylidene fluoride)/CNTs (carbon nanotubes)/Ni flexible composite films by solution mixing and 
compression molding, whose maximum EMI SE (shielding effectiveness) reached $57.3 \mathrm{~dB}$ at K-Band, with a thickness of $0.6 \mathrm{~mm}$. Lee et al. [14] fabricated PP (polypropylene)/NCCF (nickel-coated carbon fiber) composite material by mechanical mixing and injection molding, and its EMI SE was $48.4 \mathrm{~dB}$ at a frequency of $10 \mathrm{GHz}$. Some researchers have also improved the electromagnetic wave absorption capacity of composites by regulating the surface morphology of the magnetic particles [15,16].

The supercritical fluid foaming process can greatly reduce the density of the composites and fabricate a porous structure in the polymer matrix. Therefore, this technique is highly attractive as it possesses a number of benefits such as energy saving [17,18], environmental protection $[19,20]$, thermal insulation [21,22], and vibration and noise reduction [23]. A large number of studies have reported that the introduction of the microcellular structure is conducive in improving the EMI shielding properties of conductive polymer composites [24-26]. Chul B. Park's team [27] prepared an HDPE (high density polyethylene)/graphene composite foam through a supercritical fluid $\left(\mathrm{N}_{2}\right)$ injection foaming process, which exhibited higher EMI shielding effectiveness compared to solid composites and reduced the density of the composites by $26 \%$. Wang et al. [28] introduced a microcellular structure in PLA/graphite nanocomposites by an injection-molded foaming process, which improved the electrical conductivity and mechanical properties of the composite material, and its EMI shielding effectiveness reached $45 \mathrm{~dB}$. Zhang et al. [29] fabricated lightweight PVDF/Ni chain composite foams with a uniform closed-cell structure using two-step batch-foaming. The as-prepared composite foams exhibited enhanced electrical conductivity $(0.01 \mathrm{~S} / \mathrm{m})$ and EMI shielding effectiveness $(26.8 \mathrm{~dB})$. However, there are also a few studies reporting that EMI shielding performance was reduced after supercritical fluid treatment. Yang et al. [30] reported microcellular silicone rubber/MWCNTs (multi-walled carbon nanotubes) $/ \mathrm{Fe}_{3} \mathrm{O}_{4}$ nanocomposites by supercritical carbon dioxide treatment. The batch-foaming process improved the microwave-absorbing ability but diminished the EMI shielding effectiveness of the sample from $45 \mathrm{~dB}$ to $27.5 \mathrm{~dB}$. Zhang et al. [31] fabricated lightweight and multifunctional PMMA (polymethyl methacrylate) $/ \mathrm{Fe}_{3} \mathrm{O}_{4} @ \mathrm{MWCNTs}$ composite foams using the supercritical carbon dioxide foaming process. The EMI shielding effectiveness of PMMA/10 wt $\% \mathrm{Fe}_{3} \mathrm{O}_{4} @$ MWCNTs composite decreased from $25.11 \mathrm{~dB}$ to $16.0 \mathrm{~dB}$ after the supercritical carbon dioxide foaming process. The disparity in the EMI shielding performance after supercritical fluid treatment indicated that the differences in cell structure in the composite foams may cause the EMI shielding properties of the composite to differ. However, most studies focused on the effects of different nano-fillers on the foaming and EMI shielding properties of composites, while little is known in detail on the effects of cell structure with different sizes on the EMI shielding properties of composites.

Herein, to obtain composites with excellent electrical conductivity and EMI shielding performance and the mechanical properties of the PVDF/10 wt $\%$ CNTs $/ 10 \mathrm{wt} \% \mathrm{Ni}$ composites, the effect of cell structure on the composites was studied in detail. The urchin-like Ni powder was synthesized by a hydrothermal method. Then, the PVDF $/ 10 \mathrm{wt} \% \mathrm{CNTs} / 10 \mathrm{wt} \%$ $\mathrm{Ni}$ composites prepared by solution mixing and injection molding were placed in an autoclave with different saturation temperatures for the supercritical carbon dioxide foaming process. By changing the saturation temperature, the cell structure from nanoscale size to micro scale size of the composite foam is adjustable. Next, the effects of different cell structures in the composite foams on the electrical conductivity and EMI shielding properties were investigated. It is worth noting that the PVDF/10 wt $\%$ CNTs $/ 10 w t \% \mathrm{Ni}$ composites treated with supercritical carbon dioxide exhibited both enhanced electrical conductivity and EMI shielding performances. More importantly, the EMI SSE (specific shielding effectiveness) of the composite achieves $402 \mathrm{~dB} /\left(\mathrm{g} / \mathrm{cm}^{2}\right)$, which is by far the highest ever reported. 


\section{Materials and Methods}

\subsection{Raw Materials}

Nickel sulfate hexahydrate $\left(\mathrm{NiSO}_{4} \cdot 6 \mathrm{H}_{2} \mathrm{O}\right)$, sodium hydroxide, $85 \%$ hydrazine hydrate $\left(\mathrm{N}_{2} \mathrm{H}_{4} \cdot \mathrm{H}_{2} \mathrm{O}\right)$ and $\mathrm{N}, \mathrm{N}$-dimethylformamide (DMF) were purchased from Sinopharm Chemical Reagent Co., Ltd. (Shanghai, China). All reagents were of analytical grade and used without further purification. Multi-walled carbon nanotubes (MWCNTs, NC7000) were purchased from Nanocyl (Sambreville, Belgium), with an average diameter of $9 \mathrm{~nm}$ and a length of about $1.5 \mu \mathrm{m}$. The polyvinylidene fluoride 6020 (MRF: $2 \mathrm{~g} / 10 \mathrm{~min}, 230^{\circ} \mathrm{C} / 21.6 \mathrm{~kg}$ ) was provided by Solvay (Brussels, Belgium) and the $\mathrm{CO}_{2}$ gas (purity: $99.5 \%$ ) supplied by DaTong gas Co., Ltd. (Chengdu, China).

\subsection{Synthesis of Urchin-like Nickel}

According to the preparation process of An et al. [32], their study improved the synthesizing method of urchin-like nickel. Typically, first $5 \mathrm{mmol}$ of nickel sulfate hexahydrate was dissolved in a flask containing $50 \mathrm{~mL}$ of deionized water. Then, $10 \mathrm{~mL}$ of hydrazine hydrate and $0.12 \mathrm{~g}$ of $\mathrm{NaOH}$ were added. Subsequently, the mixture was magnetically stirred for $10 \mathrm{~min}$ to obtain a uniform mixture. After that, the prepared precursor was transferred into a $100 \mathrm{~mL}$ Teflon reactor and kept at $100{ }^{\circ} \mathrm{C}$ for $4 \mathrm{~h}$. Finally, the reactant was washed several times with deionized water and ethanol and separated with a permanent magnet to obtain urchin-like nickel.

\subsection{The Preparation of PVDF/CNTs/Urchin-like Ni Composites}

Flexible PVDF/CNTs/urchin-like Ni composites were prepared by solution casting and injection molding, as shown in Figure 1. First, PVDF particles were mixed with $\mathrm{N}, \mathrm{N}$-dimethylformamide solution at a ratio of $1 \mathrm{~g} / 10 \mathrm{~mL}$. After magnetically stirring at $60{ }^{\circ} \mathrm{C}$ for $3 \mathrm{~h}$, a PVDF homogeneous solution was obtained. Then $10 \mathrm{wt} \%$ of MWCNTs was added to the above mixed solution for mechanical stirring for $30 \mathrm{~min}$. Next, urchinlike Ni powders were added and ultrasonically shaken for $30 \mathrm{~min}$ to obtain a uniform PVDF/CNTs/urchin-like Ni mixture. Subsequently, the PVDF mixed solution was transferred to an evaporation dish and placed in a vacuum oven to dry at $60{ }^{\circ} \mathrm{C}$ for $5 \mathrm{~h}$. Finally, the dried PVDF/CNTs/urchin-like Ni composite films were cut off and placed in an injection molding machine to prepare a rectangular parallelepiped sample. The injection process parameters are shown in Table 1.

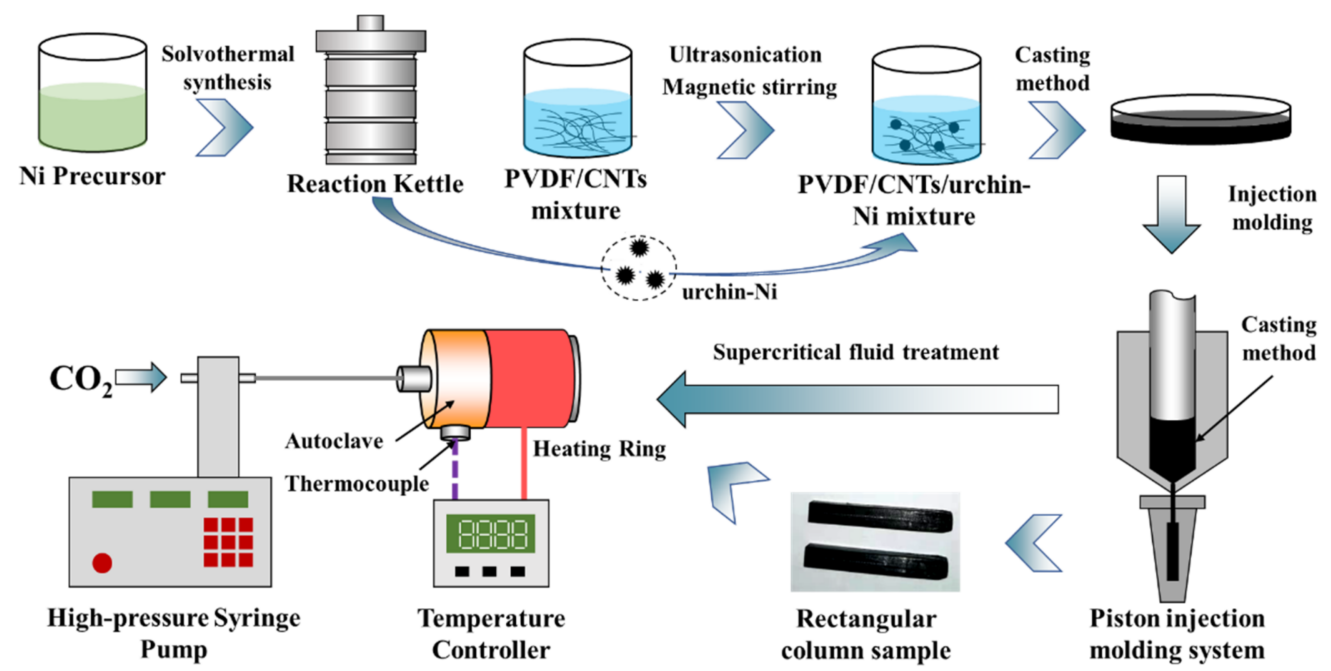

Figure 1. The preparation processing of PVDF $/ 10 \mathrm{wt} \% \mathrm{CNTs} / 10 \mathrm{wt} \%$ urchin-like Ni compo-site foams. 
Table 1. Injection process parameter settings.

\begin{tabular}{cc}
\hline Parameter Item & Set Value \\
\hline Cylinder temperature $\left({ }^{\circ} \mathrm{C}\right)$ & 245 \\
Mold temperature $\left({ }^{\circ} \mathrm{C}\right)$ & 80 \\
Injection pressure $(\mathrm{MPa})$ & 70 \\
Cooling time $(\mathrm{s})$ & 10 \\
Packing pressure $(\mathrm{MPa})$ & 60 \\
Packing time $(\mathrm{s})$ & 10 \\
\hline
\end{tabular}

\subsection{PVDF/CNTs/Ni Composites Batch-Foaming Process}

The microcellular PVDF/CNTs/Ni composites were prepared using a homemade batch foaming device, as shown in Figure 1. The batch foaming device consists of a highpressure syringe pump (ISCO 260D, Lincoln, NE, USA), an Omron temperature controller, an autoclave equipped with a temperature sensor and a ring heater, and a pressure-relief ball valve. In a typical one-step foaming process, the cavity of the autoclave was quickly purged with $\mathrm{CO}_{2}$ gas 3 times to remove the air in the autoclave. Then the sample with a size of $14 \mathrm{~mm} \times 6 \mathrm{~mm} \times 4 \mathrm{~mm}$ was put into the autoclave. Next, the gas pressure in the storage tank of the high-pressure syringe pump was kept at around $3000 \mathrm{psi}$. When the temperature inside the autoclave achieved the desired value through the temperature controller, the autoclave was filled with supercritical $\mathrm{CO}_{2}$ for $30 \mathrm{~min}$ to ensure the composite absorb $\mathrm{CO}_{2}$ completely. After the adsorption finished, the pressure-relief ball valve was quickly opened to release the high-pressure $\mathrm{CO}_{2}$ in the autoclave. Finally, the autoclave was immersed in a cold-water bath for rapid cooling to obtain a PVDF/CNTs/Ni composite foam.

To investigate the effect of different cell structure on the EMI properties of microcellular $\mathrm{PVDF} / \mathrm{CNTs} / \mathrm{Ni}$ composites, the composites were foamed in the saturation temperature range of $164{ }^{\circ} \mathrm{C}$ to $172{ }^{\circ} \mathrm{C}$, with an interval temperature of $1{ }^{\circ} \mathrm{C}$. The foamed samples were named F-164 to F-172 in this order.

\subsection{Characterization}

The crystal structure of the solid composite was examined by an X-ray diffractometer (D8 Advance, Bruker AXS, Karlsruhe, Germany) using a Cu target $(\lambda=0.15418 \mathrm{~nm})$. The density of the foamed sample was measured by a buoyancy method using a high-precision electronic balance (Sartorius, Goettingen, Germany) with a density measuring accessory. The expansion ratio $(\varphi)$ of the sample was calculated from the density of the solid sample $\left(\rho_{s}\right)$ and the density of the foamed sample $\left(\rho_{f}\right)$ in accordance with Formula (1):

$$
\varphi=\frac{\rho_{s}}{\rho_{f}},
$$

The microscopic morphology and elemental information of the as-received urchin-like $\mathrm{Ni}$ and the cross-sectional morphology of the composite foams were observed using a field emission scanning electron microscope (FE-SEM, S-4800, HITACHI, Tokyo, Japan) equipped with an energy spectrometer (Oxford Instruments, Oxford, UK). Before observation, the cross sections of the composite foams were obtained by immediately fracturing the composites after $10 \mathrm{~min}$ of immersing in liquid nitrogen, and platinum was sprayed on the surface of the cross section to eliminate the charging effect. After receiving the SEM images of the cross-section, the average cell size was measured by an open-source image processing software called ImagePy [33]. The number of counted cells is not less than 100. The cell density $\left(\mathrm{N}_{0}\right)$ of the composite was calculated by the following formula:

$$
\mathrm{N}_{0}=\left(\frac{\mathrm{n}}{\mathrm{A}}\right)^{3 / 2} \times \varphi,
$$

where $\mathrm{n}$ is the number of cells in an area of $\mathrm{A}\left(\mathrm{cm}^{2}\right)$ in the SEM image. 
The electrical conductivity is defined as $\sigma=L /(S \times R)$ (where $L$ is the length of the sample, $S$ is the cross-sectional area of the sample, and $R$ is the volume resistance of the sample). A high-precision Digital multimeter DMM 4040 (Tektronix, Beaverton, OR, USA) carried out the measurement of the resistance value $(R)$ of the composite foam. Each sample was measured 5 times to reduce the measurement error. The compression properties of the composite foams with different expansion ratios were tested on a universal material testing machine (UTM4202, SUNS, Shenzhen, China) according to ASTM-D1621. The compression specimen was a cubic specimen with a side length of $5 \mathrm{~mm}$, which was cut from the fabricated PVDF/CNTs/Ni foam. The compression speed of the crosshead during the measurement was $1 \mathrm{~mm} / \mathrm{min}$.

The EMI shielding performance of the as-prepared composite foams at different saturation temperatures was measured using a network vector analyzer (VNA, Agilent N5324A, Beijing, China) equipped with a waveguide in the K-band (18.0-26.5 GHz) frequency range. Each sample was a standard cuboid specimen with a size of $10.6 \mathrm{~mm} \times 4.3 \mathrm{~mm} \times 2 \mathrm{~mm}$ (length $\times$ width $\times$ thickness) made by cutting and grinding. The main evaluation parameters of the EMI shielding performance of the composites were as follows: reflectivity $(R)$, transmissivity $(T), S E_{\text {Total }}\left(S E_{T}\right), S E_{\text {Reflection }}\left(S E_{R}\right)$ and $S E_{\text {Absorption }}\left(S E_{A}\right)$, calculated from the forward reflection coefficient $\left(S_{11}\right)$ and reverse transmission coefficient $\left(S_{12}\right)$ measured by VNA according to the following formulas [29]:

$$
\begin{gathered}
R=\left|S_{11}\right|^{2}=\left|S_{22}\right|^{2}, \\
T=\left|S_{21}\right|^{2}=\left|S_{12}\right|^{2}, \\
S E_{R}=-10 \log _{10}(1-R), \\
S E_{A}=-10 \log _{10}\left(\frac{T}{1-R}\right), \\
S E_{T} \approx S E_{R}+S E_{A},
\end{gathered}
$$

\section{Results and Discussion}

\subsection{X-ray Diffraction Patterns and Element Analysis}

The morphology and elemental information of urchin-like Ni synthesized by the liquid phase reduction method were analyzed by SEM and EDS technology, as shown in Figure 2. The surface morphology of urchin-like Ni is shown in Figure 2a, in which the inset is an SEM image of urchin-like $\mathrm{Ni}$ at higher magnification. It can be seen from the figure that the overall diameter of urchin-like $\mathrm{Ni}$ is relatively uniform at low magnifications, with a diameter of about 1 to $2 \mu \mathrm{m}$, and the length of acicular Ni on the surface of the Ni particles is about $200 \mathrm{~nm}$ at higher magnifications. Figure $2 \mathrm{~b}$ is the point-scanning energy spectrum of the urchin-like Ni in Figure 2a. Overall, Ni is the major element in the sample, with few impurity elements $\mathrm{C}, \mathrm{O}, \mathrm{Al}$. From the relative atomic content table in Figure $2 \mathrm{~b}$, the atomic ratio of $\mathrm{Al}$ and $\mathrm{O}$ is approximately 2:3, which is likely the $\mathrm{Al}_{2} \mathrm{O}_{3}$ compound. Therefore, the impurity element could come from the aluminum-based conductive carbon tape which is used to fix the Ni powder sample. In conclusion, it can be confirmed that there was no oxidation in the prepared urchin-like Ni sample.

Figure 3 exhibits the XRD patterns of neat PVDF and PVDF/CNTs/Ni solid composite foam. First, the X-ray diffraction peaks of neat PVDF mainly appear at $2 \theta=17.6^{\circ}, 18.4^{\circ}$, $20.0^{\circ}$, and $26.7^{\circ}$, which correspond to the (100), (020), (110), and (021) crystal planes of the PVDF $\alpha$-phase, respectively [34-36]. After adding nanofillers, there was no change in the position of the diffraction peaks of PVDF, but the intensity of the diffraction peaks of PVDF crystal decreased obviously. The XRD result indicated that the addition of nanofillers did not transform the PVDF $\alpha$-phase into $\beta$-phase but blocked the formation of PVDF $\alpha$-phase. In addition, since the position of the diffraction peak of CNTs is at $2 \theta=26.5^{\circ}$, which is very close to the diffraction peak of the PVDF $\alpha$-phase (021) crystal plane, the diffraction peak of CNTs was therefore not shown in the pattern. Compared with the 
XRD pattern of neat PVDF, the XRD diffraction peaks of PVDF/CNTs/Ni composite show three extra diffraction peaks at $2 \theta=44.5^{\circ}, 51.8^{\circ}$, and $76.4^{\circ}$. According to the JCPDS no. 04-0850, these peaks correspond to the (111), (200), and (220) crystal planes of urchin-like $\mathrm{Ni}$, respectively [37]. Moreover, there are no other strong diffraction peaks other than these three diffraction peaks, which indicated that urchin-like Ni was not oxidized during the composite processing.
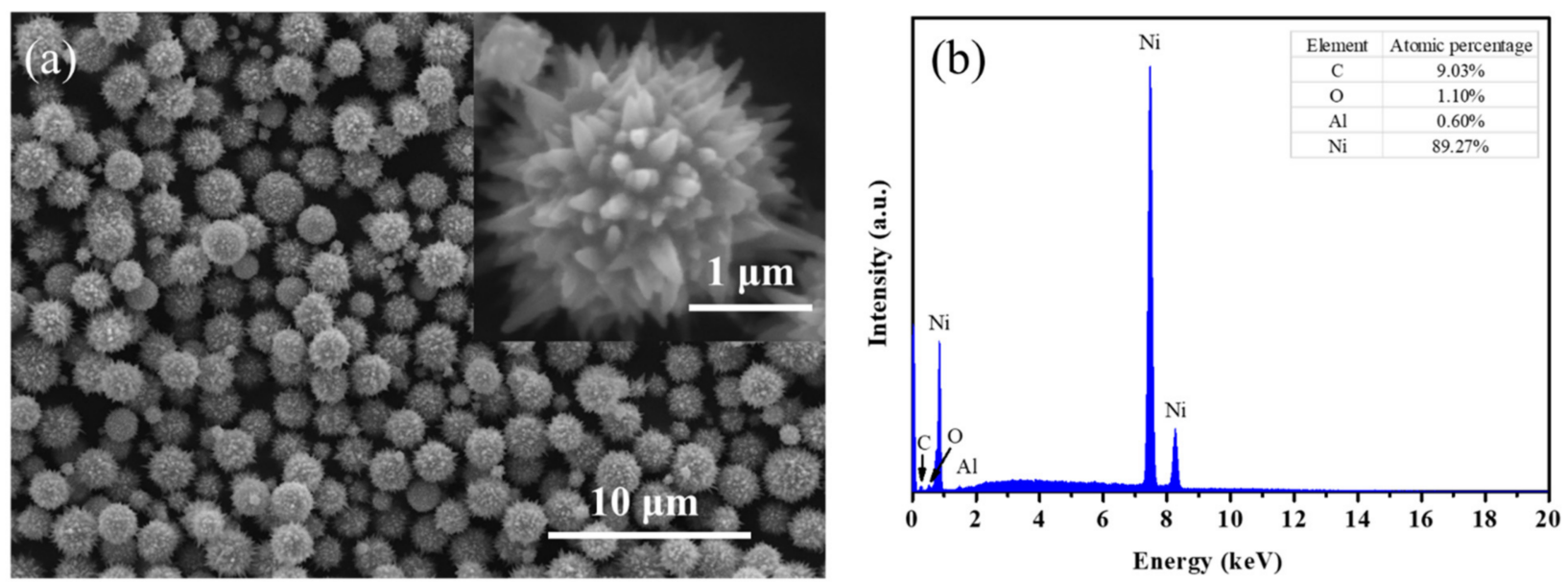

Figure 2. The SEM image (a) and EDS pattern (b) of the as-prepared urchin-like Ni particles.

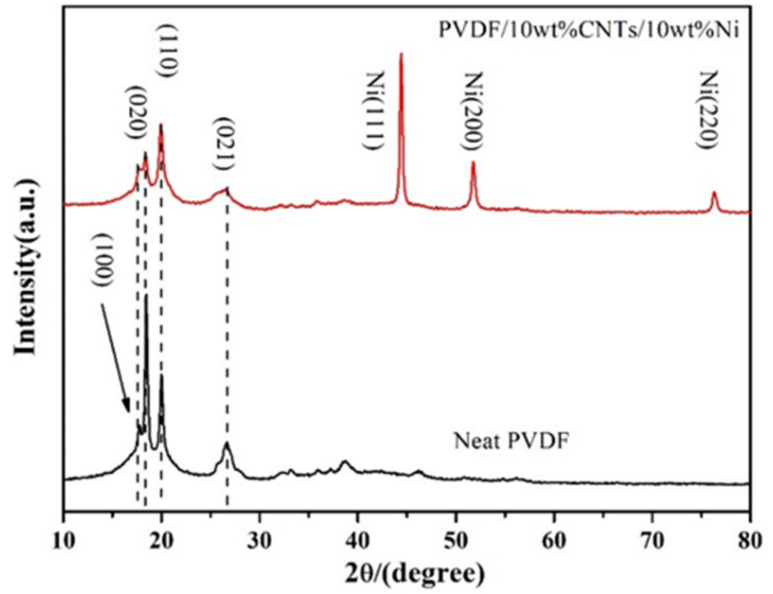

Figure 3. The XRD patterns of neat PVDF and PVDF/CNTs/urchin-like Ni composite.

\subsection{Cell Morphology of the PVDF/CNTs/Urchin-like Ni}

Figure 4 displays a cross-sectional morphology of PVDF $/ 10 \mathrm{wt} \% \mathrm{CNTs} / 10 \mathrm{wt} \% \mathrm{Ni}$ composites foamed at different saturation temperatures $\left(164-172{ }^{\circ} \mathrm{C}\right)$. As the saturation temperature increases, the cell morphology of the composite foams gradually become uniform. Because PVDF is a semi-crystalline polymer, the local melt strength of the crystalline and amorphous regions of the polymer would be distinct at different saturation temperatures [38]. In the low temperature range $\left(164-165^{\circ} \mathrm{C}\right)$, it is difficult for the cells in the polymer matrix to grow after nucleation, because the overall melt strength of the composites is too high. Eventually, nano-cells formed in the composite. When the saturation temperature increased to $166^{\circ} \mathrm{C}$, microscale cells begin to form in some amorphous regions as the melt strength of the composite decreased. When the saturation temperature further increased from $167^{\circ} \mathrm{C}$ to $169^{\circ} \mathrm{C}$, the cell morphology of the composite foams became more uniform and the cell diameter gradually increased. This is due to the crystalline region of the composites beginning to melt at the higher temperature. However, when the saturation temperature was between $170{ }^{\circ} \mathrm{C}$ and $172{ }^{\circ} \mathrm{C}$, the cell size of the composite foams decreased 
with increasing temperature. This is because the melt strength is too low, causing the cells to collapse and fuse.

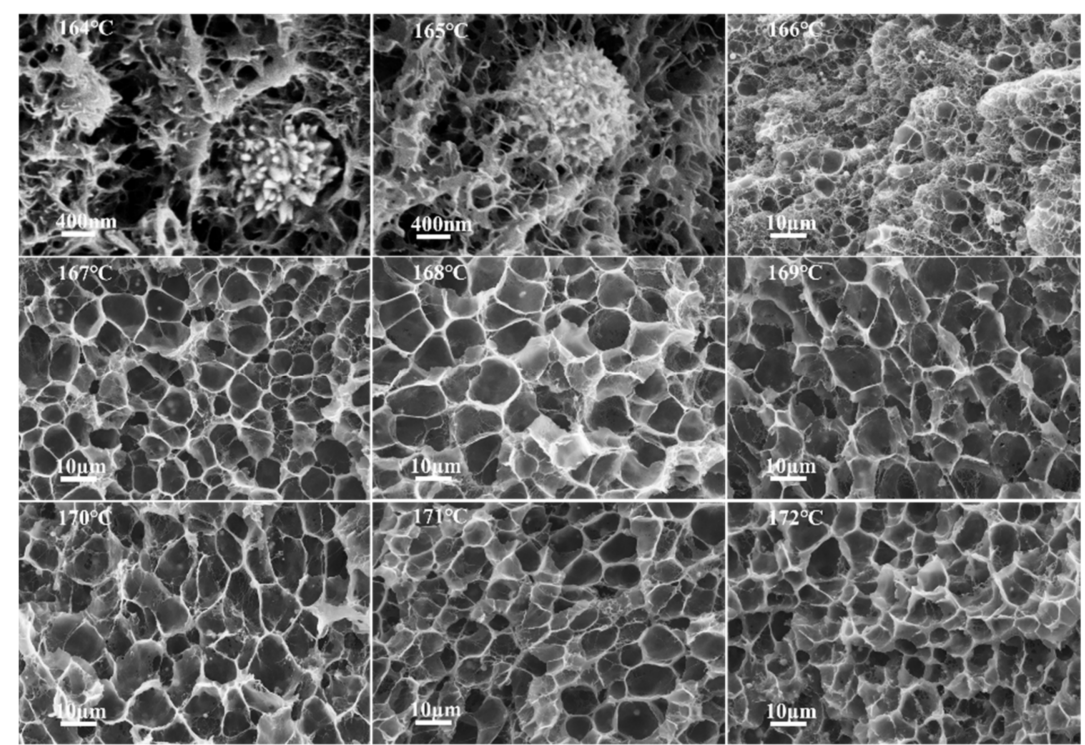

Figure 4. The SEM images of the cross-section of the PVDF $/ 10 \mathrm{wt} \% \mathrm{CNTs} / 10 \mathrm{wt} \% \mathrm{Ni}$ composites foaming under different temperature $\left(164-172{ }^{\circ} \mathrm{C}\right)$. The pictures of $164{ }^{\circ} \mathrm{C}$ and $165{ }^{\circ} \mathrm{C}$ were taken at a magnification of 20,000, and the others were taken at a magnification of 2000.

The statistical results of the expansion ratio, density, cell size, and cell density of the PVDF $/ 10 w t \%$ CNTs $/ 10 w t \%$ Ni composites foamed at different saturation temperatures are shown in Figure 5. As can be seen from Figure 5a, in the foaming temperature range $\left(164-172{ }^{\circ} \mathrm{C}\right)$, the minimum density of the composite foams is $0.515 \mathrm{~g} / \mathrm{cm}^{3}$, which is reduced to $27.2 \%$ of the original density. Compared with neat PVDF foaming performance [28], the addition of urchin-like $\mathrm{Ni}$ and CNTs reduces the maximum expansion ratio of the composite foams, which is due to the addition of urchin-like Ni increasing the viscosity of the composites and further impairing cell elastic expansion capacity. It can be seen from Figure $5 b$ that as the saturation temperature gradually increases, the cell diameter tends to grow slowly, and the cell density decreases accordingly. The maximum cell diameter and the minimum cell density were $7.26 \mu \mathrm{m}$ and $1.24 \times 10^{10}$ cells $/ \mathrm{cm}^{3}$, respectively.

(a)

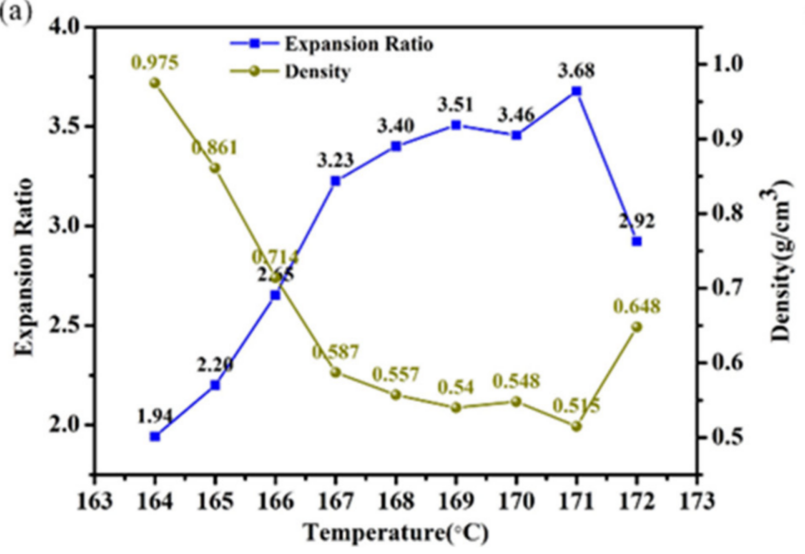

(b)

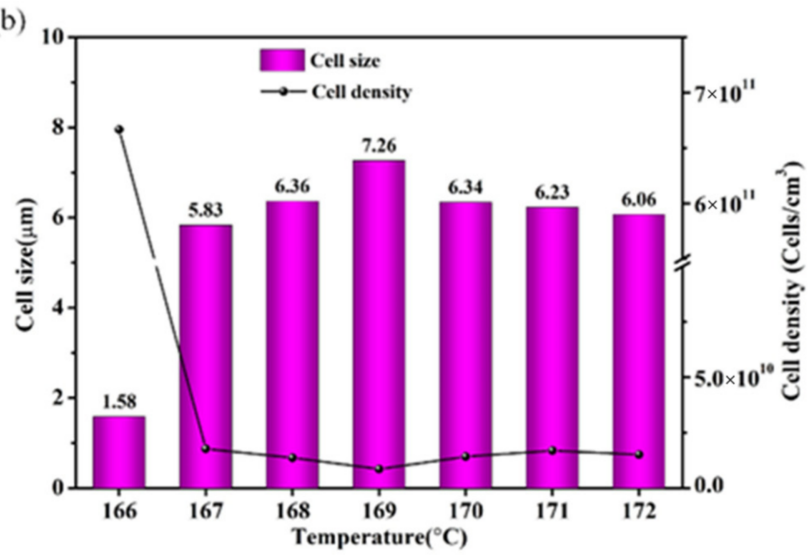

Figure 5. (a) The density and expansion ratio of the PVDF/10 $\mathrm{wt} \% \mathrm{CNTs} / 10 \mathrm{wt} \% \mathrm{Ni}$ foamed at different temperatures; (b) The cell size and cell density of the PVDF/10 wt $\%$ CNTs/10 wt $\% \mathrm{Ni}$ foamed at different temperatures. 


\subsection{Electrical and EMI Shielding Properties of the PVDF/CNTs/Ni Foams}

Figure 6 shows the electrical conductivity and EMI shielding performance of PVDF/ $10 \mathrm{wt} \% \mathrm{CNTs} / 10 \mathrm{wt} \% \mathrm{Ni}$ composites foamed at different saturation temperatures. Figure $6 \mathrm{a}$ illustrates the bar graph of the electrical conductivity of the composite foams as a function of the saturation temperature. Overall, the electrical conductivity of the composite foams initially decreases, then increases, and finally decreases which can be explained from the CNT distribution of the representative SEM images, as shown in Figure 7. In comparison to the solid PVDF/CNTs/Ni composite with an electrical conductivity of $0.06 \mathrm{~S} / \mathrm{cm}$, the composite foamed at a low temperature shows a decreased electrical conductivity due to the isolation effect of nano-scale cells on the conductive fillers. With the saturation temperature increasing from $164{ }^{\circ} \mathrm{C}$ to $166^{\circ} \mathrm{C}$, the electrical conductivity of the composite foams picks up slightly, which results from the enlarged cells in the composite foams. In the above process, one notable turning point is that the electrical conductivity of the composite foaming at $166^{\circ} \mathrm{C}$ exceeds that of the solid composite. The reason is that the microcellular cells begin to appear inside the foamed composite at this temperature, and this was proved by the SEM images shown in Figure 7. Furthermore, when the saturation temperature further increased from $166^{\circ} \mathrm{C}$ to $169^{\circ} \mathrm{C}$, the electrical conductivity of the composite foams significantly increased, with a maximum of $0.214 \mathrm{~S} / \mathrm{cm}$, which is about $250 \%$ higher than that of the solid composite. This is due to the expanding micro scale cells causing the isolated conductive fillers to concentrate on the cell walls, as is also shown in Figure 7. Meanwhile, it also indicates that micro scale size cells are more effective than nano scale size cells in constructing enhanced conductive networks. However, when the saturation temperature further increases, the electrical conductivity of the composite foams starts to decrease. Such a decrease originates from the loss in density of the conductive filler in the cell wall caused by the decreasing cell sizes. In summary, only proper cell sizes could improve the conductive properties of the composites.

Generally, the EMI shielding effectiveness is used to characterize the composites' ability to inhibit microwave radiation, which can be calculated through $S E=-10 \log _{10}\left(P_{\text {in }} / P_{\text {out }}\right)$. Usually, $\mathrm{SE}=20 \mathrm{~dB}$ shows that the material is capable of blocking $99 \%$ of microwave radiation, which is now the minimum design level of commercial EMI shielding material. The EMI shielding effectiveness of PVDF $/ 10 \mathrm{wt} \%$ CNTs $/ 10 \mathrm{wt} \% \mathrm{Ni}$ composites foamed at different saturation temperatures in the K-band (18-26.5 GHz) is shown in Figure 6b. As can be observed from the figure, the EMI shielding effectiveness of each sample does not change remarkably with increasing microwave frequency, which reveals that the composite foams exhibit independent frequency properties. In order to intuitively examine the changes in the EMI shielding effectiveness of the foamed composites at different saturation temperatures, each part of the EMI shielding effectiveness, i.e., $S E_{T}, S E_{A}$, and $S E_{R}$ of all samples at 22 $\mathrm{GHz}$ were separately extracted and compared, as shown in Figure 6c. Overall, the trend of the EMI shielding effectiveness of the composite foams with increased temperature is roughly the same as its electrical conductivity. The sudden decrease in the EMI shielding effectiveness of the F-167 sample was likely due to an accidental error during the test, which, however, does not affect the overall trend. With the saturation temperature increasing gradually, the EMI SE first increased from $13.4 \mathrm{~dB}$ to $43.4 \mathrm{~dB}$, then decreased to $22.4 \mathrm{~dB}$, and finally rose to $24.4 \mathrm{~dB}$. Compared with the solid sample, the EMI shielding effectiveness of the foamed sample improved significantly, up to $82 \%$. Notably, the absorption shielding loss $\left(S E_{A}\right)$ of all samples is much larger than their reflection shielding loss $\left(S E_{R}\right)$. For instance, the $S E_{T}, S E_{\mathrm{A}}$, and $S E_{R}$ values of the sample F-169 are $43.4 \mathrm{~dB}, 38.4 \mathrm{~dB}$, and $5.0 \mathrm{~dB}$, respectively. The absorption loss accounts for $88.5 \%$ of the total loss, which indicates that the composites treated by supercritical fluid still behave as the dominant EMI shielding mechanism. In addition, the reflection loss values $\left(S E_{R}\right)$ of the composite foams are basically maintained at about $4.5 \mathrm{~dB}$, and the change trend of the absorption loss value $\left(S E_{\mathrm{A}}\right)$ is consistent with the total shielding effectiveness trend. Thus, it can be concluded that the effect of the cell structure on the EMI shielding performance of the composite foams is mainly reflected in the change of its absorption loss, which can be explained by two 
aspects. On the one hand, the cell structure reconstructs the conductive path by changing the distribution of the conductive nanofillers in the polymer matrix, which has a vital influence on the internal current caused by microwave radiation. Meanwhile, the variation of the internal current changes the microwave losing ability of the composites $[39,40]$. On the other hand, the presence of the cell structure leads to the formation of an impedance mismatch interface between $\mathrm{CO}_{2}$ gas and composite inside the composite, which results in multiple reflection loss during the transmission of the microwave [41,42].

(a)

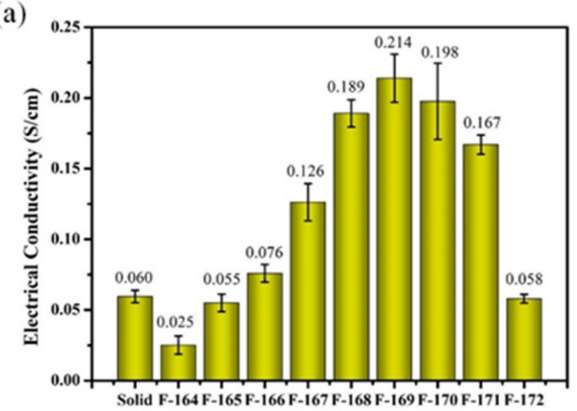

(c)

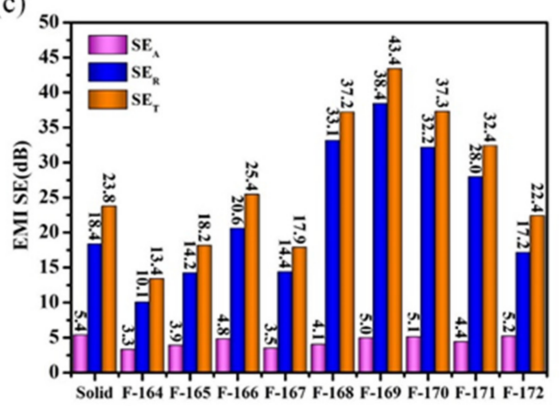

(b)

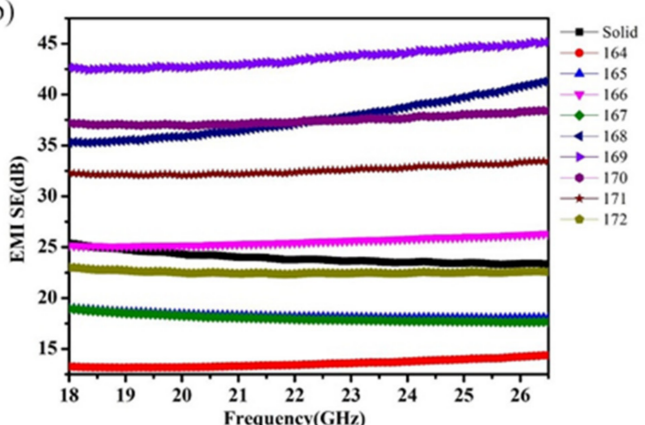

(d)

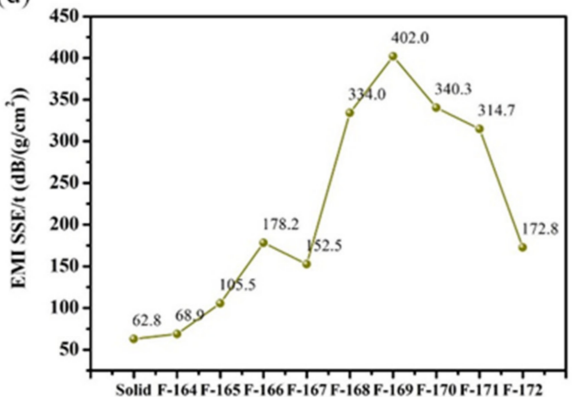

Figure 6. (a) The electrical conductivity of PVDF/10 wt $\%$ CNTs $/ 10 w t \%$ Ni composites foamed at different temperature; (b) The EMI shielding effectiveness of PVDF $/ 10 \mathrm{wt} \% \mathrm{CNTs} / 10 \mathrm{wt} \% \mathrm{Ni}$ foams at the frequency range of (18.0-26.5 GHz); (c) The $S E_{T}, S E_{A}, S E_{R}$ of PVDF/10 wt $\%$ CNTs $/ 10 \mathrm{wt} \% \mathrm{Ni}$ foams at the frequency of $22 \mathrm{GHz}$; (d) The EMI SSE/thickness of PVDF/10 wt $\%$ CNTs/10 wt $\% \mathrm{Ni}$ composites foamed at different temperature.
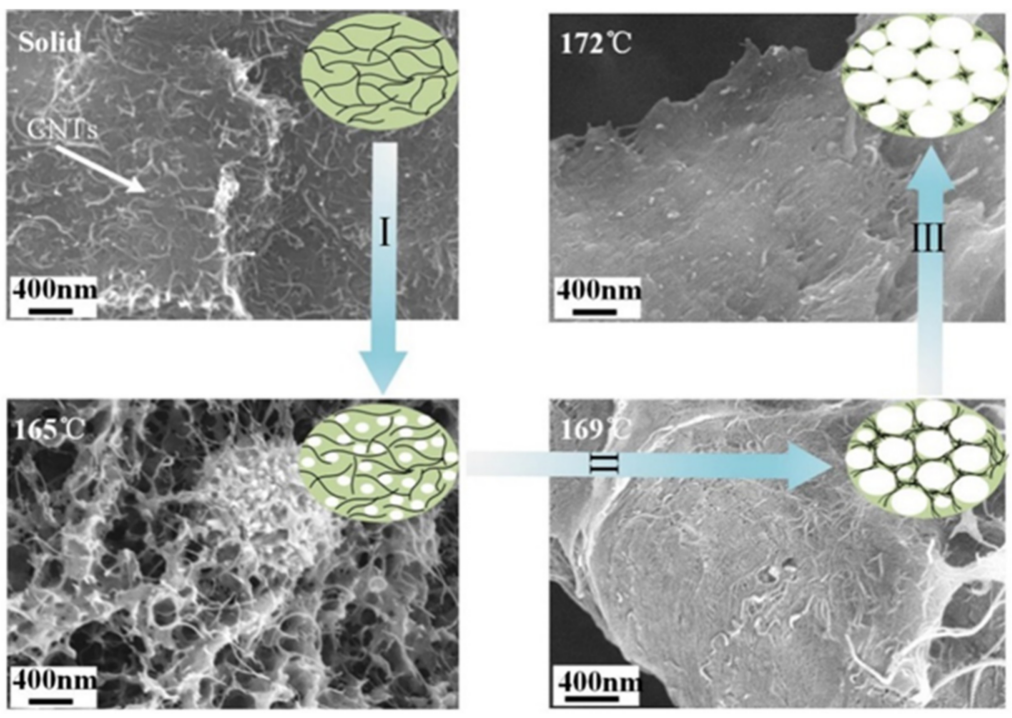

Figure 7. The SEM images of CNT distribution in solid, F-165, F-169, and F-172 samples; The inset in each image is a schematic diagram of the CNT distribution. 
Considering the strict restrictions on material density and thickness in practical applications, the EMI specific shielding effectiveness divided by the thickness (EMI SSE/t) was used to characterize the relative EMI shielding effectiveness of the PVDF/CNTs/Ni composites. Thus, the EMI SSE/thickness values of the composites foamed at different saturation temperatures were calculated and results are shown in Figure $6 \mathrm{~d}$. On the whole, the EMI SSE/ $t$ value increases first and then decreases as the saturation temperature increases, with a maximum value of $402.0 \mathrm{~dB} /\left(\mathrm{g} \cdot \mathrm{cm}^{2}\right)$ at $169^{\circ} \mathrm{C}$. Moreover, the EMI SSE/t values of all foamed samples are improved in comparison with that of the solid composite, due to the reduced density of the composites. The max EMI SSE/t value of the sample is five times that of solid composite. The result indicates that the EMI shielding property and density of the composite foam could be adjusted according to practical application by controlling the cell morphology of the composite foam.

In order to visually describe the microwave attenuating loss process when the microwaves incident the composites, a schematic diagram of the microwave attenuation mechanism of foamed and solid composite is displayed in Figure 8. When the electromagnetic wave irradiates the composite, reflection loss would occur at the interface between the external space and the composite. This is due to the impedance mismatch between air and the composite [43-45]. After microwave transmission in the composite, there are three main losses. First, the conduction loss that occurs when carriers excited by electromagnetic wave radiation conduct and transition $[46,47]$. Second, due to the high frequency alternating electric field of electromagnetic waves, interfacial polarization loss is caused by rapid exchange of excited charges between the conductive fillers (Ni and CNTs) of the composite $[48,49]$. Third, when magnetic nanoparticles are contained in the composite, the alternating magnetic field of the electromagnetic waves causes magnetic domain resonance and natural eddy currents of the magnetic substance to generate magnetic loss [50,51]. Obviously, after the composite material is processed by the supercritical $\mathrm{CO}_{2}$ foaming process, the microwave attenuation loss changes in regard of two aspects. On the one hand, the proper cell structure can improve the conductive path of the composite material, thereby improving the electrical conductivity of the composite which could increase the conductive loss of the composite [52]. On the other hand, because there is an impedance mismatch interface between the $\mathrm{CO}_{2}$ gas and the cell wall, multiple interface reflection losses take place on the cell wall, which improves the ability of the composite foam to absorb electromagnetic waves $[53,54]$.

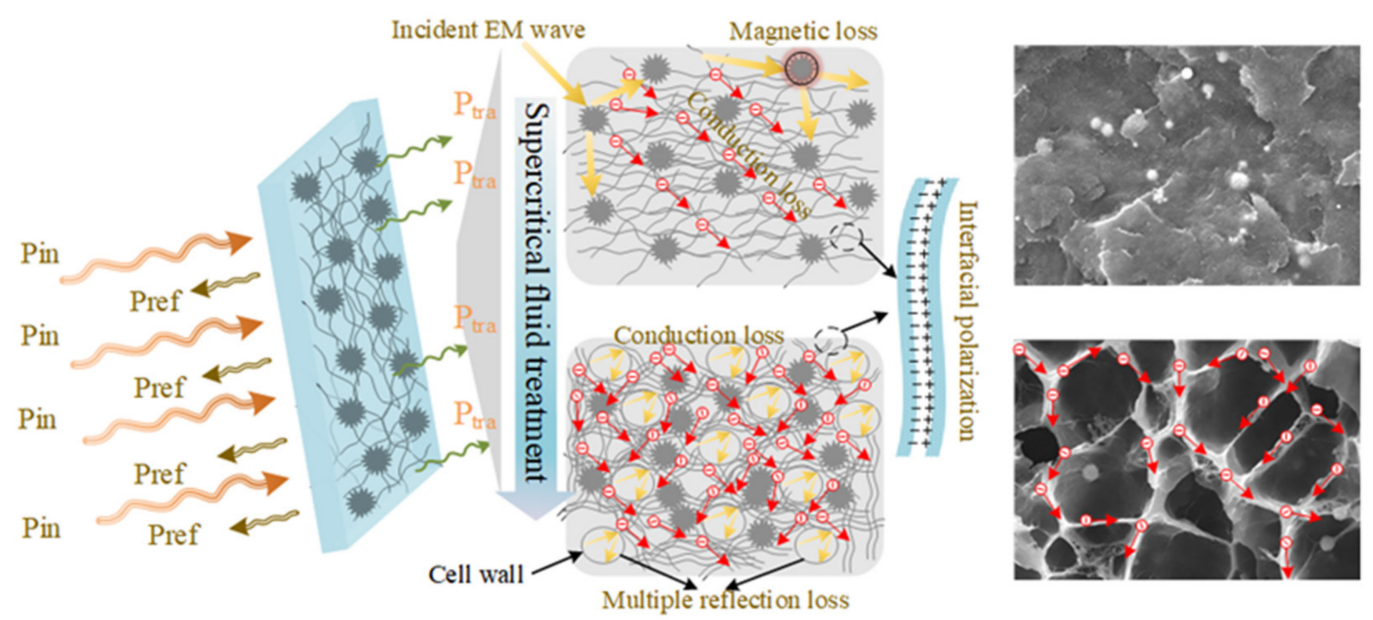

Figure 8. The schematic diagram of the microwave shielding mechanism in the solid and foamed PVDF/CNTs/urchin-like composites.

To further highlight the lightweight and high-efficiency EMI shielding performance of the prepared PVDF/CNTs/urchin-like Ni composite foams, the EMI shielding effectiveness and EMI SSE/ $t$ values of various porous composites in recent years are listed in Table 2. 
It can be seen that the porous composite prepared in the current experiment exhibits a superior EMI shielding performance compared to other porous materials, with a thickness of only $2 \mathrm{~mm}$. In particular, the composite foam exhibits an efficient EMI shielding property at low density, which results in an ultrahigh EMI SSE/t value of $402.0 \mathrm{~dB} /\left(\mathrm{g} \cdot \mathrm{cm}^{2}\right)$, higher than other materials reported in the literature. Therefore, the design and preparation method for the composite foam in this work achieved the adjustment of the EMI shielding property of the composite by changing the cell structure, which has direct significance for the performance regulation of large injection foam products. Meanwhile, it also can be applied in the fields of architecture, microelectronic devices, and aerospace.

\subsection{Compression Properties of the PVDF/CNTs/Ni Foams}

Figure 9a demonstrates the compressive stress-strain curves of PVDF/CNTs/Ni composites foamed at different saturation temperatures. It can be seen that the curves are not completely separated, which is caused by the non-uniform distribution of the cell structure in the sample. The rigid foam stress-strain curve is usually divided into three stages: linear elastic stage, yield platform, and compactness [61]. Because the cell diameter of PVDF/CNTs/Ni composite is too small, the elastic deformation phase of the cell wall is very short, which causes the compression stress-strain curves of the composite foams only to show the compaction compression phase. Therefore, the actual factor affecting the compressive strength of PVDF/CNTs/Ni composites is the solid content of the composites per unit volume. To clearly observe the compressive strength of the composite foams with different cell morphologies, the compressive strength at strain of $30 \%$ was taken out for comparison, and the bar graph is shown in Figure 9b. As can be seen, with the foaming temperature gradually increasing, its compressive strength first generally decreases and then increases slightly. The composite foamed at $164^{\circ} \mathrm{C}$ exhibits the highest compressive strength of 19.4 MPa. As the saturation temperature increases, the cell size gradually expands from the nanometer level to the micron level. Meanwhile, the compressive strength of the composite material gradually decreases as the solid content of the composite foam per unit volume gradually decreases. Then, as the temperature saturation further increases, the expansion ratio of the composite foam gradually decreases, and the cell walls become thicker. As a result, the solid content of the composite material per unit volume begins to increase again and thus the compressive strength of the composite foam picks up slightly.

Table 2. The EMI shielding effectiveness of porous composites reported in recent years.

\begin{tabular}{|c|c|c|c|c|c|c|}
\hline Matrix & Filler Loading & $\begin{array}{l}\text { Thickness } \\
\text { (mm) }\end{array}$ & $\begin{array}{l}\text { EMI SE } \\
\text { (dB) }\end{array}$ & $\begin{array}{c}\text { EMI SSE } \\
\mathrm{dB} /\left(\mathrm{g} / \mathrm{cm}^{3}\right)\end{array}$ & $\begin{array}{l}\text { EMI SSE/t } \\
\mathrm{dB} /\left(\mathrm{g} / \mathrm{cm}^{2}\right)\end{array}$ & Ref. \\
\hline PVDF & $15 \mathrm{wt} \% \mathrm{MWCNT}$ & 2.0 & 56.72 & 71.79 & 358.95 & [25] \\
\hline PMMA & $2 w t \%$ MWCNT $+1 w t \%$ GnP & 2.0 & 15.7 & 27.07 & 135.35 & [54] \\
\hline PLLA & $10 \mathrm{wt} \% \mathrm{MWCNT}$ & 2.5 & 23 & 77.00 & 308.00 & [55] \\
\hline Nature rubber & $6.4 \mathrm{wt} \% \mathrm{MWCNT}$ & 1.3 & 33.74 & 40.65 & 312.69 & {$[56]$} \\
\hline PVDF & $10 \mathrm{wt} \% \mathrm{GnPs}$ & 2.5 & 27 & 29.67 & 118.68 & [57] \\
\hline PVDF & $16 \mathrm{wt} \% \mathrm{MWCNT}$ & 2.0 & 28.5 & 45.97 & 229.85 & [9] \\
\hline TPU & $6.5 \mathrm{wt} \%$ RGO & 1.8 & 21.8 & 18.16 & 100.89 & [58] \\
\hline $\mathrm{PP}$ & $1.1 \mathrm{vol} \%$ stainless-steel fiber & 3.1 & 48 & 75.0 & 241.94 & [59] \\
\hline PEI & 10 wt $\%$ graphene@ $\mathrm{Fe}_{3} \mathrm{O}_{4}$ & 2.5 & 16.6 & 41.5 & 166.0 & [60] \\
\hline PVDF & $10 w t \% C N T s+10 w t \% \mathrm{Ni}$ & 2.0 & 43.4 & 80.4 & 402.0 & $\begin{array}{l}\text { This } \\
\text { work }\end{array}$ \\
\hline
\end{tabular}


(a)

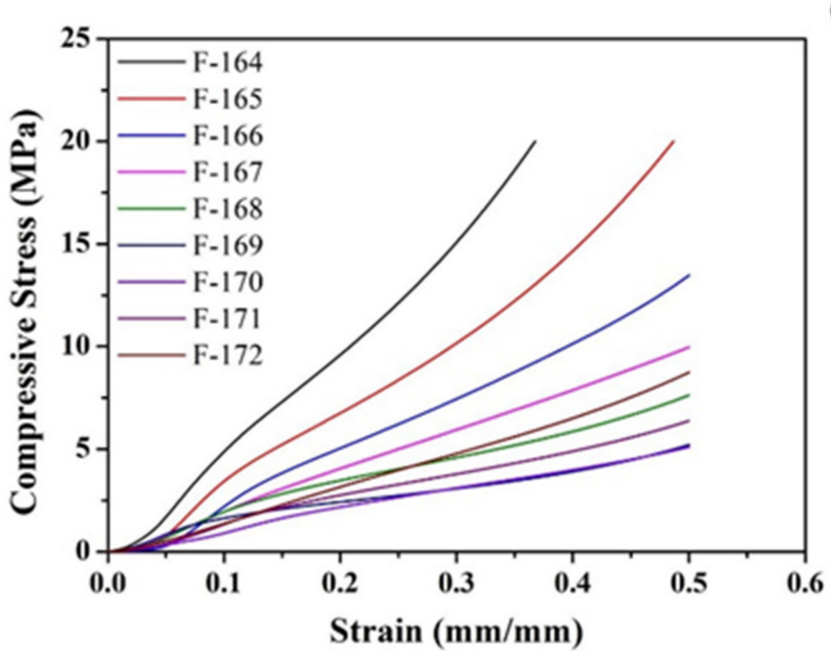

(b)

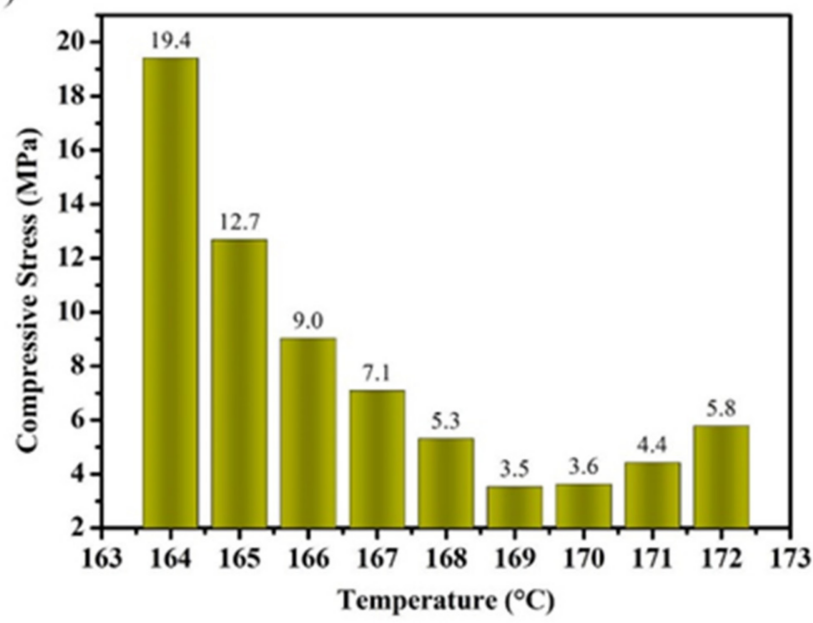

Figure 9. (a) The compressive stress-strain curves of PVDF/CNTs/Ni composites foamed at different saturation temperatures; (b) The compressive strength of composite foams at $30 \%$ strain.

\section{Conclusions}

In this work, as-synthesized urchin-like Ni and CNTs were distributed in a PVDF matrix through a casting method and injection molding to obtain a high-efficient EMI shielding composite. Then, supercritical carbon dioxide foaming treatment was performed at different saturation temperatures to fabricate porous PVDF/CNTs/Ni composites with different cell sizes. The effect of cell structure on the electrical conductivity, the EMI shielding properties of composites, and the mechanical properties were studied. It was found that the nano scale cell structure causes the EMI shielding effectiveness of the composite foam to be lower than that of the solid composite, and the micro scale cell structure with an appropriate size helps to improve the EMI shielding effectiveness of the composite. Moreover, although the introduction of urchin-like Ni and CNTs reduced the foaming properties of the composite, it improved the electrical conductivity and magnetic property of the composite to a certain extent, which resulted in an improved EMI shielding effectiveness of the composite foams to $43.4 \mathrm{~dB}$ and a maximum EMI SSE $/ \mathrm{t}$ of $402 \mathrm{~dB} /\left(\mathrm{g} / \mathrm{cm}^{2}\right)$. Finally, the mechanical properties of composite foams were investigated to determine their application prospects in engineering. The compression test shows that the composite material can maintain a compressive strength of $3.5 \mathrm{MPa}$ at a high expansion ratio. Therefore, the supercritical $\mathrm{CO}_{2}$ foaming process can improve the EMI shielding effectiveness of the composites while maintaining excellent compression performance under the appropriate process parameters.

Author Contributions: Methodology, Y.Y.; investigation, S.Z.; supervision, X.L.; resources, J.Z.; formal analysis, Z.H. All authors have read and agreed to the published version of the manuscript.

Funding: The research work was supported by Project of Key Laboratory of Urban Rail Transit Intelligent Operation and Maintenance Technology \& Equipment of Zhejiang Province, China (ZSDRTZZ2020003) and Self-Topic Fund of Zhejiang Normal University (2020ZS04), China.

Institutional Review Board Statement: Not applicable.

Informed Consent Statement: Not applicable.

Data Availability Statement: The datasets generated and analyzed during the current study are available from the corresponding author upon reasonable request.

Conflicts of Interest: The authors declare no conflict of interest. 


\section{References}

1. Zeng, Z.; Jin, H.; Chen, M.; Li, W.; Zhou, L.; Zhang, Z. Lightweight and Anisotropic Porous MWCNT/WPU Composites for Ultrahigh Performance Electromagnetic Interference Shielding. Adv. Funct. Mater. 2016, 26, 303-310. [CrossRef]

2. Shahzad, F.; Alhabeb, M.; Hatter, C.B.; Anasori, B.; Hong, S.M.; Koo, C.M.; Gogotsi, Y. Electromagnetic interference shielding with 2D transition metal carbides (MXenes). Science 2016, 353, 1137-1140. [CrossRef]

3. Wei, Q.; Pei, S.; Qian, X.; Liu, H.; Liu, Z.; Zhang, W.; Zhou, T.; Zhang, Z.; Zhang, X.; Cheng, H.; et al. Superhigh Electromagnetic Interference Shielding of Ultrathin Aligned Pristine Graphene Nanosheets Film. Adv. Mater. 2020, 32, e1907411. [CrossRef]

4. Wang, G.; Wang, L.; Mark, L.H.; Shaayegan, V.; Wang, G.; Li, H.; Zhao, G.; Park, C.B. Ultralow-Threshold and Lightweight Biodegradable Porous PLA/MWCNT with Segregated Conductive Networks for High-Performance Thermal Insulation and Electromagnetic Interference Shielding Applications. ACS Appl. Mater. Interfaces 2018, 10, 1195-1203. [CrossRef]

5. Yao, B.; Hong, W.; Chen, T.; Han, Z.; Xu, X.; Hu, R.; Hao, J.; Li, C.; Li, H.; Perini, S.E.; et al. Highly Stretchable Polymer Composite with Strain-Enhanced Electromagnetic Interference Shielding Effectiveness. Adv. Mater. 2020, 32, e1907499. [CrossRef] [PubMed]

6. Yun, T.; Kim, H.; Iqbal, A.; Cho, Y.S.; Lee, G.S.; Kim, M.; Kim, S.J.; Kim, D.; Gogotsi, Y.; Kim, S.O.; et al. Electromagnetic Shielding of Monolayer MXene Assemblies. Adv. Mater. 2020, 32, e1906769. [CrossRef]

7. Zhao, B.; Zeng, S.; Li, X.; Guo, X.; Bai, Z.; Fan, B.; Zhang, R. Flexible PVDF/carbon materials/Ni composite films maintaining strong electromagnetic wave shielding under cyclic microwave irradiation. J. Mater. Chem. C 2020, 8, 500-509. [CrossRef]

8. Zeng, S.; Li, X.; Li, M.; Zheng, J.; Shiju, E.; Yang, W.; Zhao, B.; Guo, X.; Zhang, R. Flexible PVDF/CNTs/Ni@CNTs composite films possessing excellent electromagnetic interference shielding and mechanical properties under heat treatment. Carbon 2019, 155, 34-43. [CrossRef]

9. Li, X.; Zeng, S.; Shiju, E.; Liang, L.; Bai, Z.; Zhou, Y.; Zhao, B.; Zhang, R. Quick Heat Dissipation in Absorption-Dominated Microwave Shielding Properties of Flexible Poly(vinylidene fluoride)/Carbon Nanotube/Co Composite Films with AnisotropyShaped Co (Flowers or Chains). ACS Appl. Mater. Interfaces 2018, 10, 40789-40799. [CrossRef] [PubMed]

10. Mamunya, Y.; Matzui, L.; Vovchenko, L.; Maruzhenko, O.; Oliynyk, V.; Pusz, S.; Kumanek, B.; Szeluga, U. Influence of conductive nano- and microfiller distribution on electrical conductivity and EMI shielding properties of polymer/carbon composites. Compos. Sci. Technol. 2019, 170, 51-59. [CrossRef]

11. Shi, Y.-D.; Li, J.; Tan, Y.-J.; Chen, Y.-F.; Wang, M. Percolation behavior of electromagnetic interference shielding in polymer/multiwalled carbon nanotube nanocomposites. Compos. Sci. Technol. 2019, 170, 70-76. [CrossRef]

12. Gao, W.; Zhao, N.; Yu, T.; Xi, J.; Mao, A.; Yuan, M.; Bai, H.; Gao, C. High-efficiency electromagnetic interference shielding realized in nacre-mimetic graphene/polymer composite with extremely low graphene loading. Carbon 2020, 157, 570-577. [CrossRef]

13. Zhao, B.; Wang, S.; Zhao, C.; Li, R.; Hamidinejad, S.M.; Kazemi, Y.; Park, C.B. Synergism between carbon materials and Ni chains in flexible poly(vinylidene fluoride) composite films with high heat dissipation to improve electromagnetic shielding properties. Carbon 2018, 127, 469-478. [CrossRef]

14. Lee, S.H.; Kim, J.Y.; Koo, C.M.; Kim, W.N. Effects of processing methods on the electrical conductivity, electromagnetic parameters, and EMI shielding effectiveness of polypropylene/nickel-coated carbon fiber composites. Macromol. Res. 2017, 25, 936-943. [CrossRef]

15. Feng, J.; Pu, F.; Li, Z.; Li, X.; Hu, X.; Bai, J. Interfacial interactions and synergistic effect of CoNi nanocrystals and nitrogen-doped graphene in a composite microwave absorber. Carbon 2016, 104, 214-225. [CrossRef]

16. Wang, L.; Bai, X.; Wen, B.; Du, Z.; Lin, Y. Honeycomb-like Co/C composites derived from hierarchically nanoporous ZIF-67 as a lightweight and highly efficient microwave absorber. Compos. Part B Eng. 2019, 166, 464-471. [CrossRef]

17. Zhao, J.; Wang, G.; Zhang, L.; Li, B.; Wang, C.; Zhao, G.; Park, C.B. Lightweight and strong fibrillary PTFE reinforced polypropylene composite foams fabricated by foam injection molding. Eur. Polym. J. 2019, 119, 22-31. [CrossRef]

18. Hou, J.; Zhao, G.; Zhang, L.; Wang, G.; Li, B. High-expansion polypropylene foam prepared in non-crystalline state and oil adsorption performance of open-cell foam. J. Colloid Interface Sci. 2019, 542, 233-242. [CrossRef] [PubMed]

19. Li, B.; Zhao, G.; Wang, G.; Zhang, L.; Gong, J. Fabrication of high-expansion microcellular PLA foams based on pre-isothermal cold crystallization and supercritical $\mathrm{CO}_{2}$ foaming. Polym. Degrad. Stab. 2018, 156, 75-88. [CrossRef]

20. Li, T.; Zhao, G.; Wang, G.; Zhang, L.; Hou, J. Thermal-Insulation, Electrical, and Mechanical Properties of Highly-Expanded PMMA/MWCNT Nanocomposite Foams Fabricated by Supercritical $\mathrm{CO}_{2}$ Foaming. Macromol. Mater. Eng. 2019, $304,1800789$. [CrossRef]

21. Zhao, J.; Zhao, Q.; Wang, L.; Wang, C.; Guo, B.; Park, C.B.; Wang, G. Development of high thermal insulation and compressive strength BPP foams using mold-opening foam injection molding with in-situ fibrillated PTFE fibers. Eur. Polym. J. 2018, 98, 1-10. [CrossRef]

22. Wang, G.; Zhao, G.; Dong, G.; Mu, Y.; Park, C.B.; Wang, G. Lightweight, super-elastic, and thermal-sound insulation bio-based PEBA foams fabricated by high-pressure foam injection molding with mold-opening. Eur. Polym. J. 2018, 103, 68-79. [CrossRef]

23. Rus, A.; Azahari, M.; Kormin, S.; Soon, L.B.; Zaliran, M.T.; Sadrina M. F. L., A. Hybrid waste filler filled bio-polymer foam composites for sound absorbent materials. AIP Conf. Proc. 2017, 1877, 060004. [CrossRef]

24. Naeem, S.; Baheti, V.; Tunakova, V.; Militky, J.; Karthik, D.; Tomkova, B. Development of porous and electrically conductive activated carbon web for effective EMI shielding applications. Carbon 2017, 111, 439-447. [CrossRef]

25. Wang, H.; Zheng, K.; Zhang, X.; Ding, X.; Zhang, Z.; Bao, C.; Guo, L.; Chen, L.; Tian, X. 3D network porous polymeric composites with outstanding electromagnetic interference shielding. Compos. Sci. Technol. 2016, 125, 22-29. [CrossRef] 
26. Zeng, Z.; Jin, H.; Chen, M.; Li, W.; Zhou, L.; Xue, X.; Zhang, Z. Microstructure Design of Lightweight, Flexible, and High Electromagnetic Shielding Porous Multiwalled Carbon Nanotube/Polymer Composites. Small 2017, 13, 1701388. [CrossRef]

27. Hamidinejad, M.; Zhao, B.; Zandieh, A.; Moghimian, N.; Filleter, T.; Park, C.B. Enhanced Electrical and Electromagnetic Interference Shielding Properties of Polymer-Graphene Nanoplatelet Composites Fabricated via Supercritical-Fluid Treatment and Physical Foaming. ACS Appl. Mater. Interfaces 2018, 10, 30752-30761. [CrossRef]

28. Zhao, B.; Zhao, C.; Wang, C.; Park, C.B. Poly(vinylidene fluoride) foams: A promising low-k dielectric and heat-insulating material. J. Mater. Chem. C 2018, 6, 3065-3073. [CrossRef]

29. Zhang, H.; Zhang, G.; Gao, Q.; Tang, M.; Ma, Z.; Qin, J.; Wang, M.; Kim, J.-K. Multifunctional microcellular PVDF/Ni-chains composite foams with enhanced electromagnetic interference shielding and superior thermal insulation performance. Chem. Eng. J. 2020, 379, 122304. [CrossRef]

30. Yang, J.; Liao, X.; Li, J.; He, G.; Zhang, Y.; Tang, W.; Wang, G.; Li, G. Light-weight and flexible silicone rubber/MWCNTs/Fe $\mathrm{O}_{4}$ nanocomposite foams for efficient electromagnetic interference shielding and microwave absorption. Compos. Sci. Technol. 2019, 181, 107670. [CrossRef]

31. Zhang, H.; Zhang, G.; Li, J.; Fan, X.; Jing, Z.; Li, J.; Shi, X. Lightweight, multifunctional microcellular PMMA/Fe $\mathrm{PM}_{4} @ M W C N T s$ nanocomposite foams with efficient electromagnetic interference shielding. Compos. Part A Appl. Sci. Manuf. 2017, 100, 128-138. [CrossRef]

32. An, Z.; Pan, S.; Zhang, J. Synthesis and Tunable Assembly of Spear-like Nickel Nanocrystallites: From Urchin-like Particles to Prickly Chains. J. Phys. Chem. C 2009, 113, 1346-1351. [CrossRef]

33. Anliang, W.; Xiaolong, Y.; Zhijun, W. ImagePy: An open-source, Python-based and platform-independent software package for bioimage analysis. Bioinformatics 2018, 34, 3238-3240. [CrossRef]

34. Sun, L.; Li, B.; Zhang, Z.; Zhong, W. Achieving very high fraction of $\beta$-crystal PVDF and PVDF/CNF composites and their effect on AC conductivity and microstructure through a stretching process. Eur. Polym. J. 2010, 46, 2112-2119. [CrossRef]

35. Pradhan, S.K.; Kumar, A.; Kour, P.; Pandey, R.; Kumar, P.; Kar, M.; Sinha, A.N. Tuning of dielectric and impedance properties of PVDF by incorporation of Mg doped PZT. J. Mater. Sci. Mater. Electron. 2018, 29, 16842-16852. [CrossRef]

36. Huang, T.; Yang, S.; He, P.; Sun, J.; Zhang, S.; Li, D.; Meng, Y.; Zhou, J.; Tang, H.; Liang, J.; et al. Phase-Separation-Induced PVDF/Graphene Coating on Fabrics toward Flexible Piezoelectric Sensors. ACS Appl. Mater. Interfaces 2018, 10, 30732-30740. [CrossRef]

37. Xu, W.; Wang, G.-S.; Yin, P.-G. Designed fabrication of reduced graphene oxides/Ni hybrids for effective electromagnetic absorption and shielding. Carbon 2018, 139, 759-767. [CrossRef]

38. Leung, S.N.; Lee, J.E. Tunable microcellular and nanocellular morphologies of poly(vinylidene) fluoride foams via crystal polymorphism control. Polym. Cryst. 2019, 2, 10033. [CrossRef]

39. Zhao, B.; Deng, J.; Zhao, C.; Wang, C.; Chen, Y.G.; Hamidinejad, M.; Li, R.; Park, C.B. Achieving wideband microwave absorption properties in PVDF nanocomposite foams with an ultra-low MWCNT content by introducing a microcellular structure. J. Mater. Chem. C 2020, 8, 58-70. [CrossRef]

40. Singh, A.K.; Shishkin, A.; Koppel, T.; Gupta, N. A review of porous lightweight composite materials for electromagnetic interference shielding. Compos. Part B Eng. 2018, 149, 188-197. [CrossRef]

41. Min, Z.; Yang, H.; Chen, F.; Kuang, T. Scale-up production of lightweight high-strength polystyrene/carbonaceous filler composite foams with high-performance electromagnetic interference shielding. Mater. Lett. 2018, 230, 157-160. [CrossRef]

42. Li, J.; Zhang, G.; Ma, Z.; Fan, X.; Fan, X.; Qin, J.; Shi, X. Morphologies and electromagnetic interference shielding performances of microcellular epoxy/multi-wall carbon nanotube nanocomposite foams. Compos. Sci. Technol. 2016, 129, 70-78. [CrossRef]

43. Mishra, M.; Singh, A.P.; Gupta, V.; Chandra, A.; Dhawan, S. Tunable EMI shielding effectiveness using new exotic carbon: Polymer composites. J. Alloy. Compd. 2016, 688, 399-403. [CrossRef]

44. Lee, S.H.; Yu, S.; Shahzad, F.; Kim, W.N.; Park, C.; Hong, S.M.; Koo, C.M. Density-tunable lightweight polymer composites with dual-functional ability of efficient EMI shielding and heat dissipation. Nanoscale 2017, 9, 13432-13440. [CrossRef]

45. Fang, F.; Li, Y.-Q.; Xiao, H.-M.; Hu, N.; Fu, S.-Y. Layer-structured silver nanowire/polyaniline composite film as a high performance X-band EMI shielding material. J. Mater. Chem. C 2016, 4, 4193-4203. [CrossRef]

46. Jia, L.-C.; Li, M.-Z.; Yan, D.-X.; Cui, C.-H.; Wu, H.-Y.; Li, Z.-M. A strong and tough polymer-carbon nanotube film for flexible and efficient electromagnetic interference shielding. J. Mater. Chem. C 2017, 5, 8944-8951. [CrossRef]

47. Bagotia, N.; Choudhary, V.; Sharma, D.K. A review on the mechanical, electrical and EMI shielding properties of carbon nanotubes and graphene reinforced polycarbonate nanocomposites. Polym. Adv. Technol. 2018, 29, 1547-1567. [CrossRef]

48. Wu, G.; Chen, Y.; Zhan, H.; Chen, H.T.; Lin, J.H.; Wang, J.N.; Wan, L.Q.; Huang, F.R. Ultrathin and flexible carbon nanotube/polymer composite films with excellent mechanical strength and electromagnetic interference shielding. Carbon 2020, 158, 472-480. [CrossRef]

49. Yu, W.; Zhang, G.-Q.; Liu, Y.-H.; Xu, L.; Yan, D.-X.; Huang, H.-D.; Tang, J.-H.; Xu, J.-Z.; Li, Z.-M. Selective electromagnetic interference shielding performance and superior mechanical strength of conductive polymer composites with oriented segregated conductive networks. Chem. Eng. J. 2019, 373, 556-564. [CrossRef]

50. Zhang, N.; Zhao, R.; He, D.; Ma, Y.; Qiu, J.; Jin, C.; Wang, C. Lightweight and flexible Ni-Co alloy nanoparticle-coated electrospun polymer nanofiber hybrid membranes for high-performance electromagnetic interference shielding. J. Alloy. Compd. 2019, 784, 244-255. [CrossRef] 
51. Yim, Y.-J.; Rhee, K.Y.; Park, S.-J. Electromagnetic interference shielding effectiveness of nickel-plated MWCNTs/high-density polyethylene composites. Compos. Part B Eng. 2016, 98, 120-125. [CrossRef]

52. Li, Y.; Shen, B.; Yi, D.; Zhang, L.; Zhai, W.; Wei, X.; Zheng, W. The influence of gradient and sandwich configurations on the electromagnetic interference shielding performance of multilayered thermoplastic polyurethane/graphene composite foams. Compos. Sci. Technol. 2017, 138, 209-216. [CrossRef]

53. Zeng, Z.; Wang, C.; Zhang, Y.; Wang, P.; Shahabadi, S.I.S.; Pei, Y.; Chen, M.; Lu, X. Ultralight and Highly Elastic Graphene/LigninDerived Carbon Nanocomposite Aerogels with Ultrahigh Electromagnetic Interference Shielding Performance. ACS Appl. Mater. Interfaces 2018, 10, 8205-8213. [CrossRef]

54. Zhang, H.; Zhang, G.; Tang, M.; Zhou, L.; Li, J.; Fan, X.; Shi, X.; Qin, J. Synergistic effect of carbon nanotube and graphene nanoplates on the mechanical, electrical and electromagnetic interference shielding properties of polymer composites and polymer composite foams. Chem. Eng. J. 2018, 353, 381-393. [CrossRef]

55. Kuang, T.; Chang, L.; Chen, F.; Sheng, Y.; Fu, D.; Peng, X. Facile preparation of lightweight high-strength biodegradable polymer/multiwalled carbon nanotubes nanocomposite foams for electromagnetic interference shielding. Carbon 2016, 105, 305-313. [CrossRef]

56. Zhan, Y.; Oliviero, M.; Wang, J.; Sorrentino, A.; Buonocore, G.G.; Sorrentino, L.; Lavorgna, M.; Xia, H.; Iannace, S. Enhancing the EMI shielding of natural rubber-based supercritical $\mathrm{CO}_{2}$ foams by exploiting their porous morphology and CNT segregated networks. Nanoscale 2019, 11, 1011-1020. [CrossRef]

57. Zhao, B.; Zhao, C.; Hamidinejad, M.; Wang, C.; Li, R.; Wang, S.; Yasamin, K.; Park, C.B. Incorporating a microcellular structure into PVDF/graphene-nanoplatelet composites to tune their electrical conductivity and electromagnetic interference shielding properties. J. Mater. Chem. C 2018, 6, 10292-10300. [CrossRef]

58. Jiang, Q.; Liao, X.; Li, J.; Chen, J.; Wang, G.; Yi, J.; Yang, Q.; Li, G. Flexible thermoplastic polyurethane/reduced graphene oxide composite foams for electromagnetic interference shielding with high absorption characteristic. Compos. Part A Appl. Sci. Manuf. 2019, 123, 310-319. [CrossRef]

59. Ameli, A.; Nofar, M.; Wang, S.; Park, C.B. Lightweight Polypropylene/Stainless-Steel Fiber Composite Foams with Low Percolation for Efficient Electromagnetic Interference Shielding. ACS Appl. Mater. Interfaces 2014, 6, 11091-11100. [CrossRef] [PubMed]

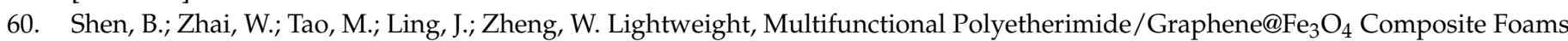
for Shielding of Electromagnetic Pollution. ACS Appl. Mater. Interfaces 2013, 5, 11383-11391. [CrossRef]

61. Hou, J.; Zhao, G.; Wang, G.; Zhang, L.; Dong, G.; Li, B. Ultra-high expansion linear polypropylene foams prepared in a semi-molten state under supercritical $\mathrm{CO}_{2}$. J. Supercrit. Fluids 2019, 145, 140-150. [CrossRef] 